\title{
Expression of dnak, groES and cps Genes in Irradiated Klebsiella pneumoniae Strains Isolated from UTI Egyptian Patients
}

\author{
Hanady Nada ${ }^{(1) \#}$, Sanaa A. Hagag ${ }^{(2)}$ and Seham El-Tablawy ${ }^{(1)}$ \\ (1)Drug Radiation Research Department, National Center for Radiation Research and \\ Technology (NCRRT), Atomic Energy Authority (AEA), Cairo, Egypt; (2)Radiology \\ Department, National Center for Radiation Research and Technology (NCRRT), \\ Atomic Energy Authority (AEA), Cairo, Egypt.
}

\begin{abstract}
$\mathbf{T}$ HIS INVESTIGATION presents a brief study for monitoring the correlation between the expression of heat-shock protein (HSP) genes; dnak, and groES as well as the capsular polysaccharide (caps) gene and antimicrobial susceptibility of extensively drug resistant (XDR) Klebsiella pneumoniae in response to a low dose of Gamma $(\gamma)$ radiation. The XDR K. pneumoniae strains, that were obtained from (UTI) Egyptian patients were identified using the API 20E strip automated system. Their antimicrobial susceptibilities were monitored using standard disc diffusion method in parallel with their minimum inhibition concentrations (MICs) towards standard antibiotics using a micro-titer method, before and after exposure to $\gamma$-radiation at a dose of 24.4 Gray (Gy). The expression of dnak, groES, and cps genes was detected by qRT-PCR under the same conditions. The results demonstrate increasing antibiotic resistance after exposure to $\gamma$-radiation. Also, a doubling in the MIC of the tested strains towards CAZ (ceftazidime) was observed. These results were confirmed by an elevation in the expression of dnak, groES, and cps genes in response to $\gamma$-radiation. These preliminary results need more confirmaions, because they assume difficulties in curing immunocompromised patients infected with XDR K. pneumoniae by the currently available antibiotics.
\end{abstract}

Keywords: Pathogenic bacteria, Virulence factor, Antibiotic resistance, Ionizing radiation, Heat-shock protein genes.

\section{Introduction}

Klebsiella pneumoniae ( $K$. pneumoniae) is a Gram-negative rod shaped bacterium. The whole bacterium surface is covered with capsular polysaccharides (CPS) that are regarded as one of its important components contributing to its virulence factors. The CPS facilitates the bacterial invasion of the host cell $(\mathrm{Wu} \& \mathrm{Li}$, 2015). In addition, it contributes to pathogenesis by mediating resistance to phagocytosis and killing by the host immune response as well as responding to the action of antibiotics (Cescutti et al., 2016). CPS is expressed in vivo and promotes the biofilm formation causing a resistance to antibiotics (Diago-Navarro et al., 2014). $K$. pneumoniae is the most predominant pathogen in urinary tract infections (UTIs) (Guermazi-Toumi et al., 2018), where it is considered the most common human infection with a wide anatomic location from kidney and bladder(upper part) to prostate and urethra (lower part). The treatment of UTIs prolonged from 7days to 12 months; depending on the site of infection, whether the infection is complicated or not, and re-infection or relapse (Najar et al., 2009). An antimicrobial resistance problem will harmfully affect the outcome treatment and has been linked to the high mortality rate in patients suffering from severe infections (Harbarth et al., 2003). Moreover, $K$. pneumoniae is commonly found as normal flora of mouth, skin and intestines as well as in natural environments. Therefore, it is easy to infect the soft tissue of immunocompromised individuals, as a result of; radiotherapy, chemotherapy, surgery, stem cell and bone marrow transplantation or steroids (Khamees et al., 2015).

Gamma rays are ionizing radiations emmitted from a radioactive source,having a high energy, short wavelength and strong transmittance that has been used in many processes as medical treatment (Shathele, 2009). The timing and dose of radiotherapy depend on the type of cancer being

"Corresponding author email: hanadynada@hotmail.com

DOI: 10.21608/ejrsa.2018.5656.1054

C2018 National Information and Documentation Center (NIDOC) 
treated and the aim of treatment whether cure or palliation (Lutz et al., 2007). Gamma-rays damage the DNA directly or by ionizing water molecules. In solutions, the ionizing radiation forms three different free radicals, through the radiolysis of water; $\mathrm{OH}$ radicals $\left({ }^{\bullet} \mathrm{OH}\right)$, the solvated electron $\left(\mathrm{e}_{\mathrm{eq}}^{-}\right)$, and the H-atom $\left({ }^{\bullet} \mathrm{H}\right)$ (Sonntag, 1978). These free radicals can destroy proteins and reactive oxygen species (Lee et al., 2001). Also, they induce DNA single or double stranded breaks (Sonntag, 1978). Consequently, this stimulates the bacterial cell to produce the major HSPs; Dnak, and GroES, that play a crucial role to overcome and repair these damages by preventing protein denaturation, aggregation, and to reactivate partially denatured proteins (Maleki et al., 2016). These HSPs were translated from mRNA dnak and groES genes (Cardoso et al., 2010). In agreement with Laport et al. (2006), who noted that not only changes in temperature trigger the HSPs expression in bacteria. Caillet et al. (2008) noticed a significant induction of Dnak and GroES proteins in E. coli in response to $\gamma$-radiation at dose $0.4-1.3 \mathrm{kGy}$.

To our knowledge, limited studies have been carried out to evaluate the significance of $\gamma$-irradiation on HSPs expression genes encoding HSPs in K. pneumoniae strains and their virulence. Therefore, the objective of this study is conducted to monitor the effect of low dose of $\gamma$-radiation at $24.4(\mathrm{~Gy})$, which is biologically equivalent to invitro fractionated multiple therapeutic dose of some cancer patients (Barton, 1995), on the expression of HSP genes, dnak and groES as HSP genes and cps as the most important virulence factor of $K$. pnumoniae strains, in parallel with reporting the change in their antibiotic resistance.

\section{Materials and Methods}

\section{Urine collection}

Early morning midstream urine samples (about $100 \mathrm{ml}$ ) were collected from patients suffering from UTIs at the microbiology laboratory at Ain-Shams University Hospital, Egypt. The samples were collected in sterile tightly locked containers.

\section{Isolation and identification}

The collected urine samples were cultured separately on MacConkey agar (Oxoid, England). Twenty five isolates were identified as Klebsiella $s p$. on the basis of their typical colonial appearance (viscous/mucoid characteristic colonies), Gram stain to determine their microscopic shape and arrangement. The non-motile, Gram-negative, lactose fermenter, encapsulated, non-spore forming rode shape bacterium that tested catalase positive and oxidase negative underwent a further identification using API 20E strip automated system (BioMe'rieux, France), as shown in (Fig. 1). The culture was maintained at $4^{\circ} \mathrm{C}$ on nutrient agar slants.

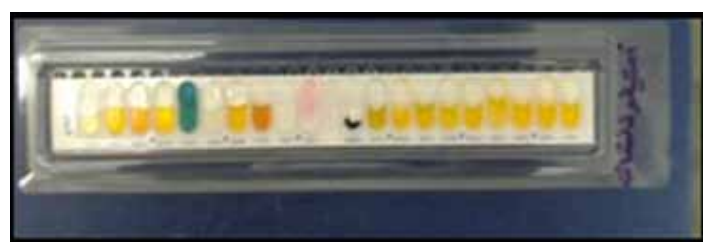

Fig. 1. Identification of Klebsiella pneumoniae by API20E.

\section{Antimicrobial susceptibility}

All identified K. pneumoniae strains were tested for their susceptibilities to antibiotics by standard disk diffusion susceptibility method (Wayne, 2017). The standard antibiotic disks (Oxoid, England) were chosen as they are commonly used in UTI treatment in local hospitals and recommended worldwide (Alabsi et al., 2014 and Arslan et al., 2005). They included the following antibiotic groups; amoxycillin-clavulanic acid

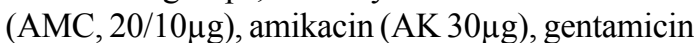
$(\mathrm{CN}, 10 \mu \mathrm{g})$, aztreonam (ATM, 30 $\mu \mathrm{g})$, ceftazidime

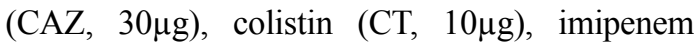
(IMP, 10 $\mu \mathrm{g}$ ) and trimethoprim-sulfamethoxazole (SXT, 1.25/23.75 $\mu \mathrm{g}$ ). Pure colonies (3-5) were recultured in Luria-Bertani (LB) broth for $3 \mathrm{~h}$ at $37^{\circ} \mathrm{C}$ and adjusted to $0.5 \mathrm{McF}$ arland standard. Then, they swabbed on the top of the solidified MuellerHinton $(\mathrm{MH})$ agar plate and allowed to dry for 10 min. Then, antibiotic disks were placed individually on the surface of the medium and left for $30 \mathrm{~min}$. at room temperature. The plates were incubated at $32 \pm 2^{\circ} \mathrm{C}$ for $18-24 \mathrm{~h}$. Zones of inhibition were recorded in $\mathrm{mm}$ and compared with a standardized chart supplied by (Oxoid-England). The test was repeated in triplicate (the results not shown).

\section{Minimum inhibitory concentration (MIC)}

The MIC is defined as the lowest concentration of the tested antibiotic that inhibited $90 \%$ of bacterial growth. The XDR $K$. pneumoniae strains (three) were slected to estimate the MIC of ceftazidime (CAZ) [Fortum ${ }^{\circledR} 1 \mathrm{~g}$-GlaxosmithKline, kindly provided by The National Organization for Drug Control and Research (NODCR)-Egypt]. Fortum (ceftazidime) was selected according to 
CLSI-2007 guidelines because it is inexpensive and a readily available antibiotic, also, it is routinely used in Egyptian hospitals. The 96-well microtitre assay using resazurin as an indicator of cell growth was employed (Sarker et al., 2007). Under aseptic conditions; the CAZ powder was dissolved with sterile distilled water, a volume of $100 \mu \mathrm{l}$ of antibiotic dilution $(1000 \mu \mathrm{g} / \mathrm{ml})$ was pipetted into the first row of the plate. To all other wells, $50 \mu \mathrm{l}$ of normal saline was added. Serial dilutions were performed. Each well had $50 \mu$ l of the tested antibiotic in serially descending concentrations (from 1000 to $0.24 \mu \mathrm{g} / \mathrm{ml}$ ). To each well, $10 \mu \mathrm{l}$ of the resazurin indicator solution was added. Finally, $10 \mu \mathrm{l}$ of the selected bacterial suspension prepared as in (2.5 method) and was added to each well. The plate had a set of controls: a column with all solutions with the exception of the tested antibiotic, another column with all solutions with the exception of the bacterial suspension adding $10 \mu \mathrm{l}$ of nutrient broth instead. The plates were prepared in triplicate and placed in an incubator set at $32^{\circ} \mathrm{C}$ for $18-24 \mathrm{~h}$. The color change was then assessed visually. Any color changes from purple to pink or colorless were recorded as positive indications. MIC was determined as the lowest antibiotic concentration at which color change occurred. The average of the three values was calculated and was the MIC for $\mathrm{CAZ}$ and $K$. pneumoniae isolates.

\section{Irradiation process}

Three different bottles, each one containing $100 \mathrm{ml}$ of tryptone soya broth (TSB) inoculated with pure colonies; $K_{1}, K_{2}$, and $K_{3}$ respectively, then they were incubated for $3 \mathrm{~h}$ at $32 \pm 2^{\circ} \mathrm{C}$, the turbidity was adjusted to $0.5 \mathrm{McF}$ arland. Each bottle was divided under sterile conditions, into another two sterile and autoclaved bottles. The $1^{\text {st }}$ bottle was used as a control (non irradiated). While, the second one was irradiated in Gamma cell 40 irradiator occupied by Cesium $137\left({ }^{137} \mathrm{Cs}\right)$, Atomic Energy of Canada Limited, Commercial products located at The National Center for Radiation Research and Technology (NCRRT), Atomic Energy Authority, Cairo, Egypt. The radiation dose rate was 0.688 $\mathrm{rad} / \mathrm{sec}$ at the time of the experiments. The $1^{\text {st }}$ and $2^{\text {nd }}$ bottles for each isolate were used for different investigations.

\section{Primer design}

The complete genomes of different Klebsiella pneumoniae strains were downloaded from the National Center for Biotechnology Information (NCBI) GenBank database (https://www.ncbi.nlm. nih.gov/nucleotide/). The design of cps primers was based on finding a short length of conserved sequence in multiple different $K$. pneumoniae strain's genome. Multiple sequence alignment was performed by CLUSTAL W Multiple Sequence Alignment Program (Larkin et al., 2007). Primer design was performed using Primer 3 (version 0.4.0) and in Silico PCR software. 16S rRNA was used as reference gene (housekeeping gene) (Christensen et al., 2004 and Lim et al., 2007). All primers were purchased from (Jena Bioscience, Germany) with the sequences shown in (Table 1).

TABLE 1. Primer sequences, expected product length for amplification of 16S rRNA, dnak, groES, and $c p s$ genes in Klebsiella pneumoniae strains.

\begin{tabular}{|c|c|c|c|c|}
\hline \multirow{2}{*}{ Gene } & Primer sequence & \multirow{2}{*}{$\begin{array}{c}\text { NCBI accession No./ } \\
\text { Template }\end{array}$} & \multirow{2}{*}{ Amplicon loci } & \multirow{2}{*}{$\begin{array}{l}\text { Amplicon size } \\
\text { (bp) }\end{array}$} \\
\hline & $5, \quad-\quad 3$ & & & \\
\hline 16S rRNA* & $\begin{array}{c}\text { Fd AGTCATGAATCACAAAGTGGTAAGCG } \\
\text { Rv } \\
\text { AGGGCTACACACGTGCTACAATG }\end{array}$ & UNIVERSAL & NA & $267 \mathrm{bp}$ \\
\hline dnak & $\begin{array}{l}\text { Fd TGGTGGTCAGACTCGTATGCCGAT } \\
\text { Rv ATCGCCACGGCTTCATCCGGGTTA }\end{array}$ & $\begin{array}{c}\text { CP025088.1 Klebsiella } \\
\text { pneumoniae strain KP7 } \\
\text { chromosome }\end{array}$ & $\begin{array}{l}548505- \\
548603\end{array}$ & 99 bp \\
\hline groES & $\begin{array}{c}\text { Fd } \\
\text { TCGTCCGTTACATGATCGTGTG } \\
\text { Rv } \\
\text { TGCAGAACCGGTCAGAACGA }\end{array}$ & $\begin{array}{l}\text { CP025088.1 Klebsiella } \\
\text { pneumoniae strain KP7 } \\
\text { chromosome }\end{array}$ & $\begin{array}{l}148398- \\
148482\end{array}$ & $85 \mathrm{bp}$ \\
\hline$c p s$ & $\begin{array}{c}\text { Fd } \\
\text { AGAGTGGAATCTGCGTGCAA } \\
\text { Rv } \\
\text { AGGCTCGCTTGGGTTTCTG }\end{array}$ & $\begin{array}{c}\text { LT174552.1 Klebsiella } \\
\text { pneumoniae capsular } \\
\text { polysaccharide } \\
\text { biosynthesis gene } \\
\text { cluster, type: K39 }\end{array}$ & $12161-12486$ & $327 \mathrm{bp}$ \\
\hline
\end{tabular}

$\mathrm{bp}=$ base pair * House keeping gene

All these primers were designed at this study 


\section{Extraction of RNA and cDNA preparation}

Immediately, after irradiation, one and half $\mathrm{ml}$ of $1 \times 10^{9}$ of each irradiated $K_{1}, K_{2}$, and $K_{3}$ was transferred alone to a microcentrifuge tube, centrifuged for $2 \mathrm{~min}$ at $(12,000 \mathrm{xg})$ and $4^{\circ} \mathrm{C}$. Then, each pellet was washed twice using the cooling isotonic solution for preparing RNA extraction. Then, RNA extraction was carried out using GeneJET RNA purification kit (Fermentus, Thermo Fisher Scientific Inc, UK) according to manufacturer's instructions. A $1 \mu \mathrm{l}$ sample of purified RNA was read on the nanodrop 2000 spectrophotometer (Thermo Scientific, USA) at OD 260\280nm gave 1.8- 2 (Boom et al., 1990). Then, they were adjusted to the same concentration, and same quantities were used for synthesis of cDNA according to the instructions of high capacity RNA-to-cDNA Kit (Fermentus, Thermo Fisher Scientific Inc, UK).

\section{Quantitative real-time PCR ( $q R T-P C R$ )}

Quantitative Real-time PCR was used as a sensitive method for quantification of the gene expression. qRT-PCR amplification for dnak, groES, and cps cDNA in each isolates of $K$. pneumoniae before (as control) and after exposure to low dose $\gamma$-radiation (24.4Gy) was accomplished in (a Rotor-Gene 2000 real-time fluorescence thermal cycler, (Corbett Ltd., Australia). The reaction was prepared in $25 \mu \mathrm{l}$ containing $1 \mathrm{X}$ of GoTaq ${ }^{\circledR}$ Master Mix (Promega, USA), 10pmol of primer and $1 \mu \mathrm{l}$ of earlier reverse transcription reaction prepared cDNA product. In addition to, theDyNAmo ${ }^{\text {TM }}$ Syber green fluorescent qPCR Kits (Finnzymes Oy, Finland) was used to quantify the progression of amplification. The programs for amplifications are, 1 cycle $95^{\circ} \mathrm{C}$ for $5 \mathrm{~min}$ for predenaturation. fEach one of the forty cycles consists of $95^{\circ} \mathrm{C}$ for $40 \mathrm{sec}, 60^{\circ} \mathrm{C}$ of annealing for $40 \mathrm{sec}$ and $72^{\circ} \mathrm{C}$ of extension for $20 \mathrm{sec}$. The PCR conditions were optimized to produce the least non-specific signals by primer dimers, as evaluated by earlier amplification melting curve analysis. Each cDNA fragment was amplified in triplicate for each gene as well as $16 \mathrm{~S}$ rRNA.

The specificity of the amplicons was verified by building the melting curves for the PCR products. It is very important for each gene to detect the number of cycles required for the fluorescent signals to cope with the background level; called the threshold cycle $\left(\mathrm{C}_{\mathrm{t}}\right)$ and it was detected automatically. Then, we calculated $2^{-\Delta \Delta C}$ to obtain the change in the gene expression by normalizing them by housekeeping gene and relative to control gene, before exposure to $\gamma$-radiaton (Livak \& Schmittgen, 2000).

\section{Statistical analysis}

Three replicates were performed for each experiment. Then, the data were expressed as (Mean \pm Standard deviation) and paired t-test for testing antibiotics before and after irradiation using Sigma plot 10.0. Differences were considered statistically significant at $(\mathrm{P} \leq 0.05) .2^{-\Delta \Delta \mathrm{Ct}}$ method was used to obtain the change in the gene expression by normalizing them by housekeeping gene and relative to control gene (Livak \& Schmittgen 2000).

\section{$\underline{\text { Results and Discussion }}$}

K. pneumoniae causes about $14-20 \%$ of severe infections leading to complications with high morbidity and mortality rates, up to $40 \%$ in some hospitals (Lepper et al., 2003). In addition, they are the second most predominant pathogen that causes UTIs with long treatment period (Najar et al., 2009), especially in immunocompromised individuals (Wu \& Li, 2015).

In the current study, twenty five clinical isolates of $K$. pneumoniae were isolated from UTIs by the microbiology laboratory at Ain-Shams University Hospital, Egypt and identified by API 20E strip. The antibiotic resistance profile of all isolates were tested against eight antibiotics with different mode of actions (Table 2). Out of them, three isolates $\left(K_{1}, K_{2}\right.$, and $\left.K_{3}\right)$ were selected for further studies as they showed a high resistance towards the tested antibiotics, to evaluate the effect of 24.4Gy (accumulative dose of $\gamma$-radiation that use in radiotherapy) on their antibiotic sensitivity and gene expression of dnak, groES, and cps .

The results in (Fig. 2) indicated that their resistance was significantly increased with P-value $<0.05$ after exposure to gamma radiation dose. This result was additionally confirmed by an increase in the MIC of $K_{2}$, and $K_{3}$ by double fold for ceftazidime, from 16 to $\sim 32 \mu \mathrm{g} / \mathrm{ml}$ for both strain (Fig. 3). This is may be due to the overexpression of proteins after expoure to $\gamma$-radiation. The results of the present study agreed with Mortazavi et al. (2017) who reported that there were significant reductions in bacterial susceptibility to antibiotics especially in $K$. pneumoniae after exposure to $\gamma$-radiation with with inhibition zone $20.3 \mathrm{~mm}$ of and $14.7 \mathrm{~mm}$, respectively. 

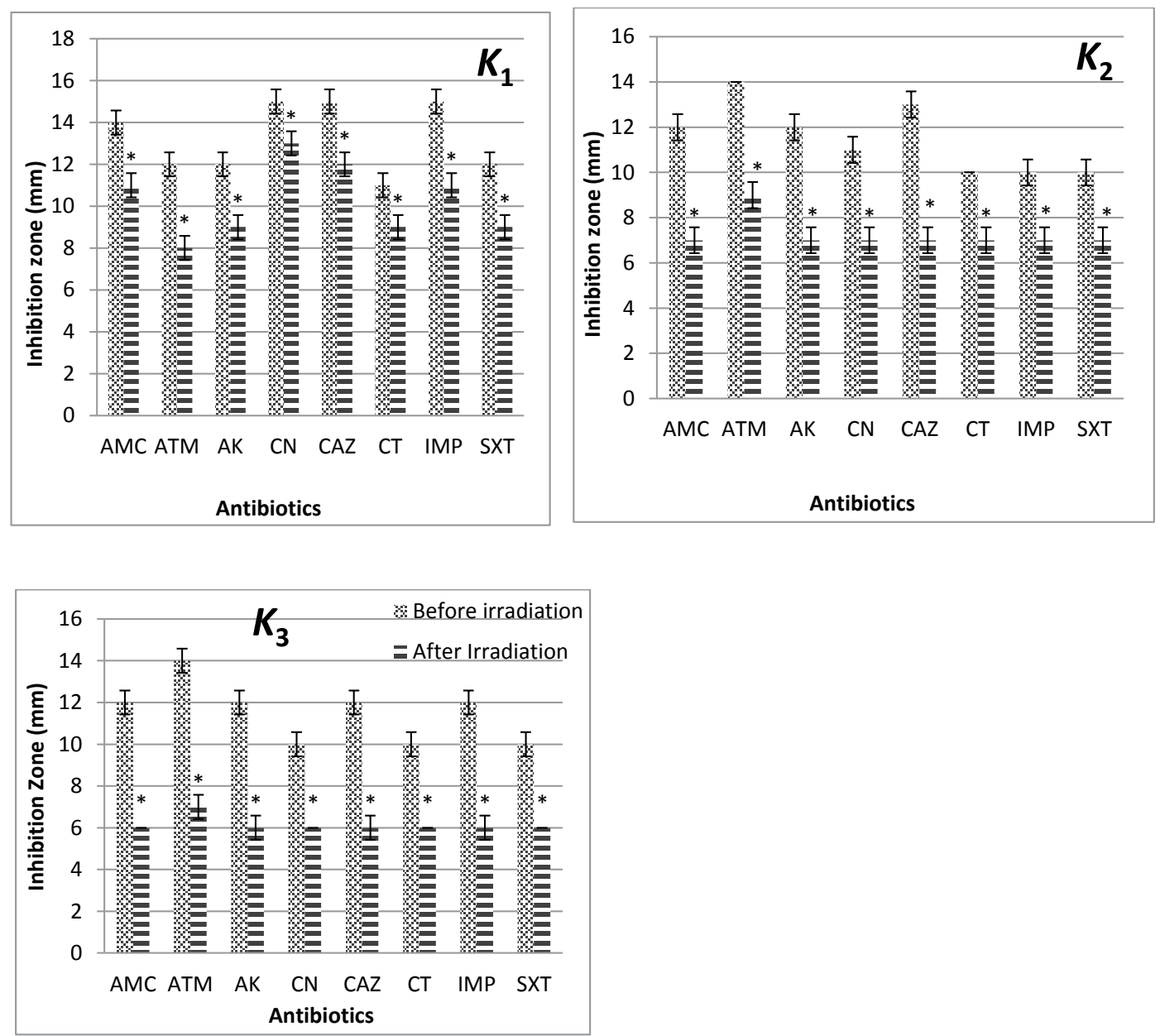

Fig. 2. Antimicrobial susceptibility of $K_{1}, K_{2}$, and $K_{3}$ before and after irradiation at dose 24.4Gy. AMC: Amoxycillin-

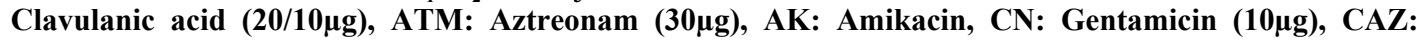

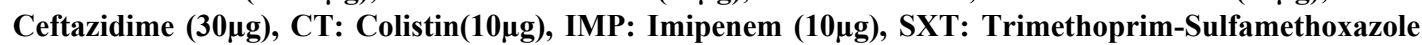
$(1.25 / 23.75 \mu \mathrm{g})(*$ significant $P$ value $\leq 0.05$, Error bars represent standard deviation).

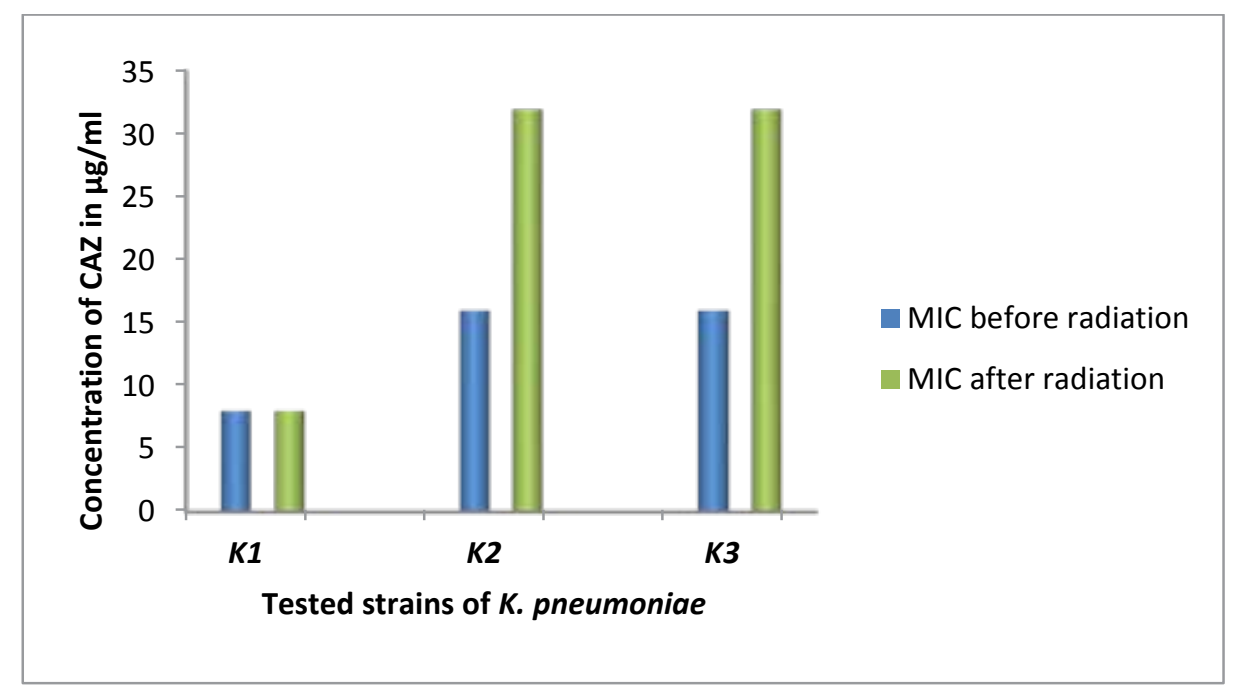

Fig. 3. Minimum inhibitory concentration of ceftazidime (CAZ) for the XRD strains of $K$. pneumoniae $\left(K_{1}, K_{2}\right.$, and $\mathrm{K}_{3}$ ) before and after exposure to $24.4 \mathrm{~Gy}$. 
Quantitative RT-PCR was performed as a sensitive method to quantify the gene expression of dnak and groES that quickly translated to Dnak and GroES proteins as reported by Vanghele et al. (2016). The transcriptional changes in those genes were procured from the threshold cycles $\left(\mathrm{C}_{\mathrm{t}}\right)$ which are obtained from the qRT-PCR performance as shown in (Table 3). The results of the present study revealed that the highest gene expression was shown by dnak in $K_{1}, K_{2}$, and $K_{3}$. ,this is in agreement with Calini et al. (2003), who reported that Dnak was highly induced in response to gamma radiation as a radioprotective mechanism towards the first event of DNA damage and increases long-term viability. A similar profile of dnak, groES, and cps genes expression in irradiated $K_{1}, K_{2}$, and $K_{3}$ (Fig. 4) suggests the presence of a common mechanism tracked by the $K$. pneumoniae to overcome and repair the protein damages in response to the external stress of $\gamma$-radiation and this perhaps trigger on or act simultaneously with the virulence and antibiotic resistance machinery to maintain the cell survival.

In contrast to the present results, Yamaguchi et al. (2003) demonstrated that the dnak genes have an influence on the antimicrobial activity of the fluoroquinolone in E. coli and mutations in them increased the bacterial susceptibility to levofloxacin. Furthermore, Singh et al. (2007) noticed, in Staphylococcus aureus methicillinresistant strain, a mutation in the $d n a K$ gene which increased their susceptibility to oxacillin and methicillin.

As for the $c p s$, the main virulence gene in $K$. pneumoniae, the results in Table 2 revealed upregulation by $1.5,2.5$ and $\sim 2$ fold in irradiated $K_{1}, K_{2}$, and $K_{3}$, respectively. Gomide et al. (2018) reported that in many pathogens, virulence factors are under control of transcriptional activators, any stress leading to the expression of virulence genes at $37{ }^{\circ} \mathrm{C}$ as reported in L. monocytogens. Also, the present results are in agreement with Pallen (1989) who noticed that the oxidative stress on Vibrio cholera was switched on its virulence genes and increases the production of Dnak and GroE proteins. However, the present results are in contrast with Lim et al. (2007) who noticed 3- to 1000-fold reduction in the expression of virulence gene levels located within the pathogenicity island on the chromosome of Salmonella typhimuriumand Vibrio toxin genes of some Vibrio spp. as food borne pathogens after exposing to 0.5 and $1 \mathrm{kGy}$ of $\gamma$-radiation. This conflict with the present results may be due to the diffrence in the type of organism or the $\gamma$-radiation dose.

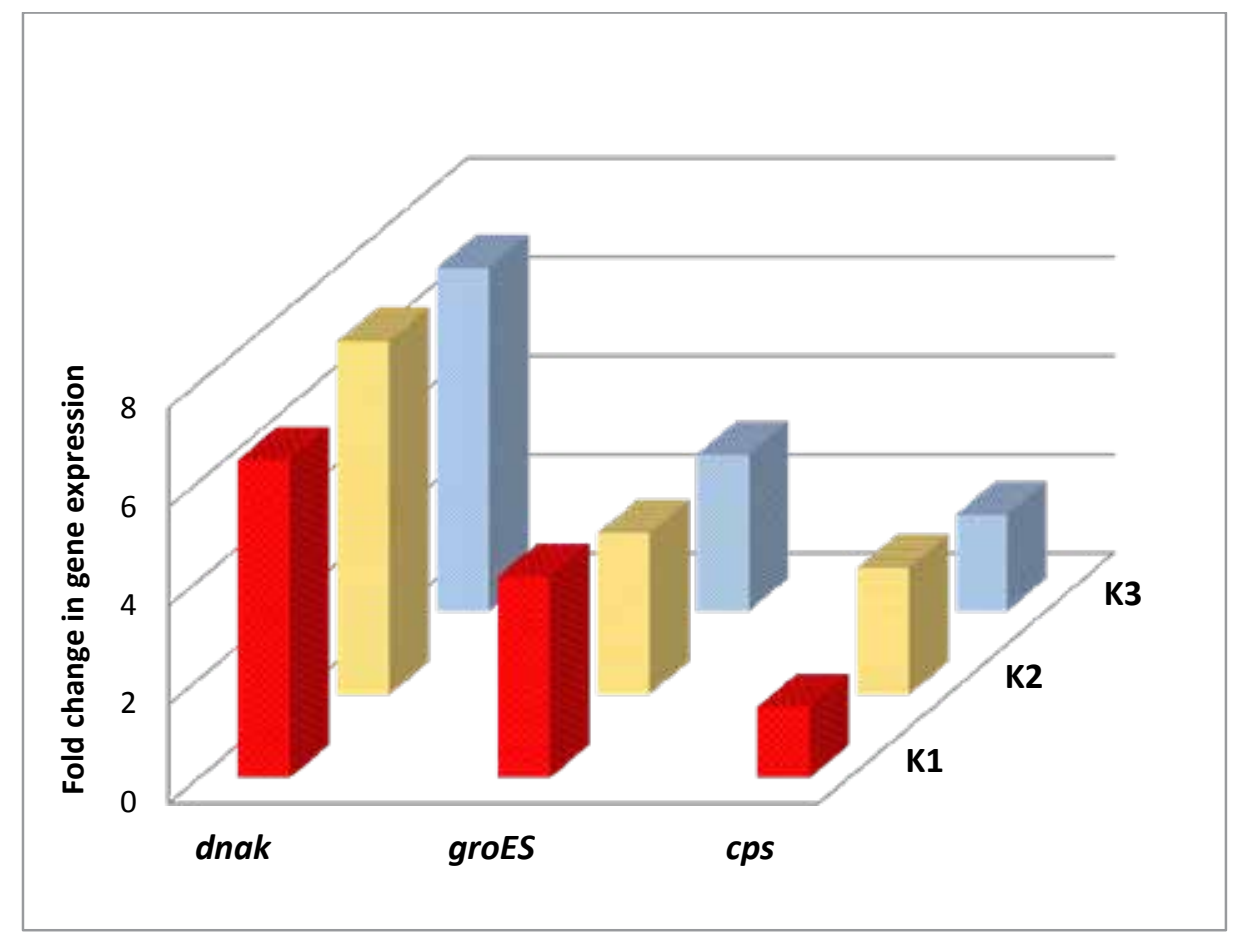

Fig. 4. Response of dnak, groES, and cps genes in K. pneumoniae to 24.4Gy dose of irradiation. 
TABLE 2. Gene expression of $d n a k$, groE, and cps mesured by RT-PCR in XRD K. pneumoniae after exposure to 24.4Gy dose of $\gamma$-irradiation.

\begin{tabular}{|c|c|c|c|c|}
\hline \multirow{2}{*}{ Strain } & \multirow{2}{*}{ Gene } & \multicolumn{2}{|c|}{ Cycle threshold $\left(C_{t}\right) *$} & \multirow{2}{*}{$2_{t}^{-\Delta \Delta C^{* *}}$} \\
\hline & & Before irradiation & After irradiation & \\
\hline \multirow{3}{*}{$\mathrm{K}_{1}$} & dnak & $30.96 \pm 1.04$ & $28.27 \pm 1.4$ & 6.45 \\
\hline & groES & $32.29 \pm 1.87$ & $30.26 \pm 0.69$ & 4.08 \\
\hline & cps & $31.46 \pm 0.25$ & $30.92 \pm 0.92$ & 1.45 \\
\hline \multirow{3}{*}{$\mathrm{K}_{2}$} & dnak & $33.03 \pm 0.45$ & $30.19 \pm 1.0$ & 7.16 \\
\hline & groES & $31.4 \pm 1.58$ & $29.22 \pm 0.75$ & 4.53 \\
\hline & cps & $30.75 \pm 0.8$ & $29.39 \pm 0.38$ & 2.57 \\
\hline \multirow{3}{*}{$\mathrm{K}_{3}$} & dnak & $31.22 \pm 2.144$ & $28.42 \pm 0.42$ & 6.96 \\
\hline & groES & $32.29 \pm 2.0$ & $31.26 . \pm 0.36$ & 2.04 \\
\hline & cps & $30.36 \pm 1.34$ & $29.39 \pm 1.18$ & 1.96 \\
\hline
\end{tabular}

${ }^{*} \mathrm{C}_{\mathrm{t}}$ values are the means $\pm \mathrm{SD}$ of RT-PCR analysis performed three replicates.

** Calculated by method of (Livak \& Schmittgen, 2000).

\section{Conclusion}

This study is limited, just to spotlight on the fact thata low dose of $\gamma$-radiation may cause an increase in the expression of the HSP genes as dnak, and groES which trigger other virulence genes in $K$. pneumoniae as cps gene, which contribute to increasing their resistance towards the normal used antibiotics. It is possible that this may pose a therapeutic problem in immunocompromised persons, such as cancer patients receiving $\gamma$-radiation therapy. Further studies are required to confirm the expression of these genes in infected cancer patients before and after receiving their radiotherapy sessions.

\section{$\underline{\text { References }}$}

Alabsi, M.S., Ghazal, A., Sabry, S.A. and Alasaly, M.M. (2014) Association of some virulence genes with antibiotic resistance among uropathogenic Escherichia coli isolated from urinary tract infection patients in Alexandria, Egypt: A hospitalbased study. JGAR, 2(2), 83-86.

Arslan, H.A; Ö.K., Ergönül, Ö. and Timurkaynak, F. (2005) Risk factors for ciprofloxacin resistance among Escherichia coli strains isolated from community-acquired urinary tract infections in Turkey. J. Antimicrob. Chemoth. 56(5), 914-918.

Barton, M. (1995) Tables of equivalent dose in 2 Gy fractions: a simple application of the linear quadratic formula. Int. J. Radiat. Oncol. Biol. Phys. 31(2), 371-378.
Boom, R., Sol, C.J., Salimans, M.M., Jansen, C.L., Wertheim-van, Dillen, P.M. and Van der, N.J. (1990) Rapid and simple method for purification of nucleic acids. J. Clin. Microbiol. 28(3), 495-503.

Caillet, S., Millette, M., Dussault, D., Shareck, F. and Lacroix, M. (2008) Effect of gamma radiation on heat shock protein expression of four foodborne pathogens. J. Appl. Microbiol, 105(5), 1384-1391.

Calini,V., Urani, C. and Camatini, M. (2003) Overexpression of HSP70 is induced by ionizing radiation in $\mathrm{C} 3 \mathrm{H} 10 \mathrm{~T} 1 / 2$ cells and protects from DNA damage. Toxicology in vitro, 17(5-6), 561566.

Cardoso, K., Gandra, R.F., Wisniewski, E.S., Osaku, C.A., Kadowaki, M.K., Felipach-Neto, V., Haus, A.A. and Simão, R.C.G. (2010) DnaK and GroEL are induced in response to antibiotic and heat shock in Acinetobacter baumannii. J. Med. Microbiol. 59(9), 1061-1068.

Cescutti, P., De Benedetto, G. and Rizzo, R. (2016) Structural determination of the polysaccharide isolated from biofilms produced by a clinical strain of Klebsiella pneumoniae. Carbohydr. Res. 430, 29-35.

Christensen, H., Kuhnert, P., Olsen , J.E. and Bisgaard, M. (2004) Comparative phylogenies of the housekeeping genes $a t p D$, inf $B$ and $r p o B$ and the 16S rRNA gene within the Pasteurellaceae. Int. J. Syst. Evol. Microbiol. 54(5), 1601-1609.

Diago-Navarro, E., Chen, L., Passet, V., Burack, S., 
Ulacia-Hernando, A., Kodiyanplakkal, R.P., Levi, M.H., Brisse, S., Kreiswirth, B.N. and Fries, B.C. (2014) Carbapenem-resistant Klebsiella pneumoniae exhibit variability in capsular polysaccharide and capsule associated virulence traits. The Journal of Infectious Diseases, 210(5), 803-813.

Gomide, A.C.P., de Sá, P.G., Cavalcante, A.L.Q., de Jesus, S.T., Gomes, L.G.R., Ramos, R.T.J., Azevedo, V., Silva, A. and Folador, A.R.C. (2018) Heat shock stress: Profile of differential expression in Corynebacterium pseudotuberculosis. Biovar. Equi. Gene. 645, 124-130.

Guermazi-Toumi, S., Boujlel, S., Assoudi, M., Issaoui, R., Tlili, S. and Hlaiem, M. E. (2018) Susceptibility profiles of bacteria causing urinary tract infections. Southern Tunisia. J. of Global Antimicrobial Resistance, 12, 48-52.

Harbarth, S., Garbino, J., Pugin, J., Romand, J.A., Lew, D. and Pittet, D. (2003) Inappropriate initial antimicrobial therapy and its effect on survival in a clinical trial of immunomodulating therapy for severe sepsis. Am. J. Med. 15(7), 529-535.

Khamees, A.A., Abdelbary, N.M., Elmasry, E.A. and Gohar, S.F. (2015) Incidence of MRSA infection in pneumonia in cancer patients with phenotyping \& genotyping study. EJCDT, 64(3), 689-691.

Laport, M.S., Dos Santos, L.L., Lemos, J.A., Maria do Carmo, F.B., Burne, R.A. and GiambiagideMarval, M. (2006) Organization of heat shock $d n a K$ and groE operons of the nosocomial pathogen Enterococcus faecium. Research in Microbiology, 157(2), 162-168.

Larkin, M.A., Blackshields, G., Brown, N.P., Chenna, R., McGettigan, P.A., McWilliam, H., Valentin, F., Wallace, I.M., Wilm, A. and Lopez, R. (2007) Clustal W and Clustal X version 2.0. Bioinformatics, 23(21), 2947-2948.

Lee, S.J., Choi, S.A., Lee, K.H., Chung, H.Y., Kim, T.H.; Cho, C.K. and Lee, Y.S. (2001) Role of inducible heat shock protein 70 in radiation-induced cell death. Cell Stress Chaperones, 6(3), 273-281.

Lepper, P.M., Möricke, A., Held, T.K., Schneider, E.M. and Trautmann, M. (2003) K-antigen-specific, but not $\mathrm{O}$-antigen-specific natural human serum antibodies promote phagocytosis of Klebsiella pneumoniae. FEMS Immunol. Med. Microbiol. 35(2), 93-98.

Lim, S., Jung, J. and Kim, D. (2007) The effect of $\gamma$ radiation on the expression of the virulence genes of Salmonella typhimurium and Vibrio spp. Radiat. Phys. Chem. 76(11-12), 1763-1766.

Livak, K.J. and Schmittgen, T.D. (2000) Analysis of relative gene expression data using real-time quantitative PCR and the $2-\Delta \Delta \mathrm{CT}$ method. Methods, 25(4), 402-408.

Lutz, S.T., Chow, E.L., Hartsell, W.F. and Konski, A.A. (2007) A review of hypofractionated palliative radiotherapy. Cancer, 109(8), 1462-1470.

Maleki, F., Afra Khosravi, A.N., Taghinejad, H. and Azizian, M. (2016) Bacterial heat shock protein activity. $J C D R, 10(3), \mathrm{BE} 01-\mathrm{BE} 03$.

Mortazavi, S.M.J., Zarei, S., Taheri, M., Tajbakhsh, S., Mortazavi, S.A., Ranjbar, S., Momeni, F., Masoomi, S., Ansari, L. and Movahedi, M.M. (2017) Sensitivity to antibiotics of bacteria exposed to gamma radiation emitted from hot soils of the high background radiation areas of Ramsar. Northern Iran. Int. J. Occup. Environ. Med. 8(2 April), 80-84.

Najar, M., Saldanha, C. and Banday, K. (2009) Approach to urinary tract infections. Indian J.Nephrol. 19(4), 129-139.

Pallen, M. (1989) Bacterial heat-shock proteins and serodiagnosis. Serodiagnosis and Immunotherapy in Infectious Disease, 3(3), 149-159.

Sarker, S.D., Nahar, L. and Kumarasamy, Y. (2007) Microtitre plate-based antibacterial assay incorporating resazurin as an indicator of cell growth, and its application in the in vitro antibacterial screening of phytochemicals. Methods, 42(4), 321-324.

Shathele, M. (2009) Effects of gamma irradiation on fungal growth and associated pathogens. RJET, 3(2), 94-100.

Singh, V.K., Utaida, S., Jackson, L.S., Jayaswal, R.K., Wilkinson, B.J. and Chamberlain, N.R. (2007) Role for dnaK locus in tolerance of multiple stresses in Staphylococcus aureus. Microbiology, 153(9), 3162-3173. 
Sonntag, C. (1987) "The Chemical Basis of Radiation Biology". $1^{\text {st }}$ ed. Taylor \& Francis London, New York, NY.

Vanghele, L.M., Ionescu, M., Coste, H. G. and Elena, G. (2016) Association of DnaK and GroEL with antimicrobial resistance in Salmonella Abortusovis. Journal of Veterinary Medicine: Research \& Reports, 2016, 1-11.

Wayne, P. (2017) Clinical and laboratory standards institute. Performance standards for antimicrobial susceptibility testing. standards M02-A12, M07-A10, and M11-A8.
Wu, M. and Li, X. (2015) "Klebsiella pneumoniae and Pseudomonas aeruginosa, in Molecular Medical Microbiology". $2^{\text {nd }}$ ed. Elsevier, pp. 1547-1564.

Yamaguchi ,Y., Tomoyasu, T., Takaya, A., Morioka, M. and Yamamoto, T. (2003) Effects of disruption of heat shock genes on susceptibility of Escherichia coli to fluoroquinolones. $B M C$ microbiology, 3(1), 16.

(Received 14/10/2018; accepted 26/ 12/2018)

\section{التعبير الجيني dnak, groES and cps لسلالات كليبسيلا نيمونيا المشععه والمعزوله من مرضى إلتهاب المسالك البوليه المصرينين}

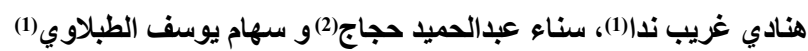

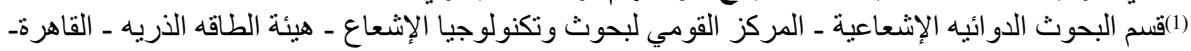

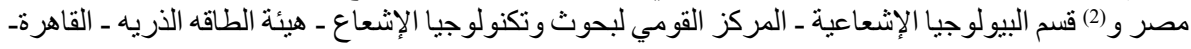

يدرس هذا البحث بإختصار العلاقه بين جينات الصدمه الحراريه dnak , groES مع جين الكبسوله عديدة

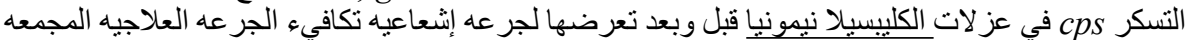
التي يحصل علَيها بعض مرضى السرطان عند علاجهم بالإشعاع.

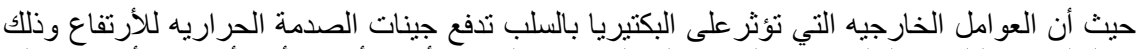

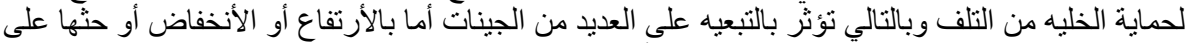

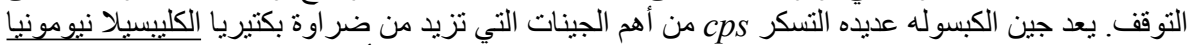

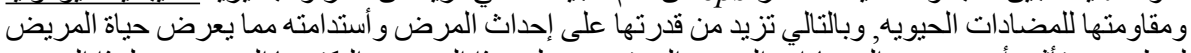

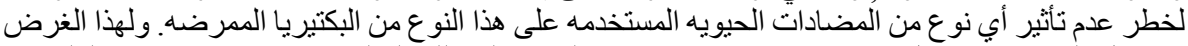

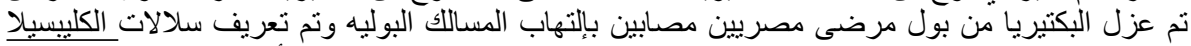

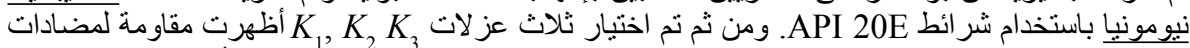

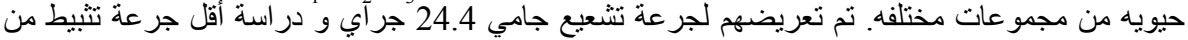

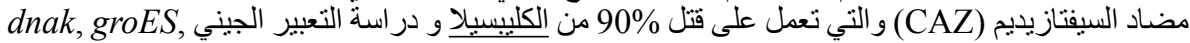

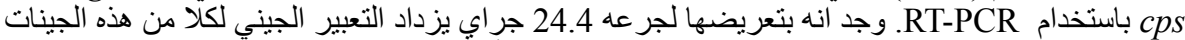

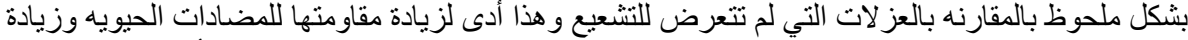

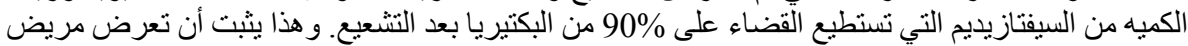

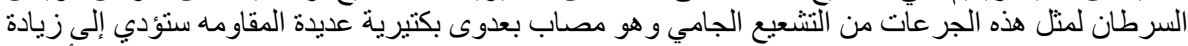

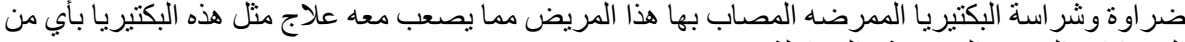
المضادات الحيو يه المعروفة المبرة والمتداولة. 